\title{
Contributions of Music Therapy on Perceptive Physiological of Well-Being of Alcohol and Drug Users
}

\author{
Domingos-Souza Gean ${ }^{1 *}$, Mariana Ferreira Sousa ${ }^{2}$, Carlos Albertos Sellis ${ }^{2}$ and Jessica Adrielle Teixeira Santos ${ }^{3}$ \\ ${ }^{1}$ Department of Biomedical Sciences, University of Missouri, USA \\ ${ }^{2}$ Paulista State University, Brazil \\ ${ }^{3}$ Department of Psychiatric Nursing and Human Sciences, University of São Paulo, Brazil \\ Submission: February 08, 2018; Published: February 13, 2018 \\ *Corresponding author: Domingos-Souza Gean, Department of Biomedical Sciences, Department of Medical Pharmacology and Physiology, Dalton \\ Cardiovascular Research Center, University of Missouri, 134 Research Park Drive, Columbia, MO, 65211, USA, Tel: +1 352815 6797; \\ Email: geandomingosusp@gmail.com
}

Abstract

Music therapy is a flexible treatment modality, able to promote wellness, facilitate symptom management, and improve the quality of life of those with mental illnesses. Also, the use of music therapy in individuals who abuse alcohol and drugs contributes to an increase in the perceptive physiological of well-being, and this may directly implicate the way in which they adhere to treatment.

Keywords: Physiological; Music therapy; Illicit drugs; Alcoholism; Psychiatric nursing

Abbreviations: CAPSad: Centers for Psychosocial Support Alcohol and Drugs

\section{Introduction}

\section{The Therapeutic Side of Music - Physiological Benefits}

From the beginnings of civilization music accompanies man throughout his life, and among other meanings it acts as a way of arousing feelings [1]. Music can also behave with a remedy for the mind and body as it affects the physical, emotional, cognitive and social needs of individuals of all ages. Research and clinical experience leave little doubt that music influences neural processing. Trained music therapists harness this ability to effect therapeutic change across multiple treatment domains [2]. Music therapy is a flexible treatment modality, able to promote wellness, facilitate symptom management, and improve the quality of life of those with mental illnesses. Qualified, credentialed music therapists use active and passive music therapy interventions to target specific objectives like improving mood, increasing compliance and motivation, and enhancing emotional expression. Data suggest that music therapy intervention results in clinical improvement in individuals with a range of mental health needs, and these benefits are seen among individuals with varying diagnoses, ages, and ethnicities. The data also suggest that music therapy is cost effective, has little adverse effects, and is well received by those with mental illnesses [3].

\section{Music Therapy for Addiction}

In Brazil, public policies and national guidelines determine that health care for individuals with diagnoses of problems related to the use of psychoactive substances should preferably be performed at the Centers for Psychosocial Support Alcohol and Drugs (CAPSad) [4]. Besides the use of conventional treatment techniques, these health services prioritize psychosocial interventions as the main strategy of socialization and social inclusion, as well as music therapy. The music therapy workshops in a therapeutic environment have minimized through the playfulness the patients' difficulties in performing the most diverse treatments, where it becomes possible to better communicate with these patients, showing them in a more understandable way the relationship between coping with problems and prepare them to face new situations $[5,6]$. In this sense, evidence shows that music provides a facilitating environment in the process of recovering users [7]. Other studies have found the benefits of music therapy in different clinical situations, influencing physiological variations that include even cardiac parameters (blood pressure, heart rate), respiratory, nervous (electroencephalogram), as well as endocrine and immune systems improvement [8-11]. 


\section{Intervention in Locus}

Aiming to explore the benefits of music therapy, the authors verified the impact of the use of music therapy on the Subjective Well-Being of alcohol and drug users enrolled in a Psychosocial Alcohol and Drug II Care Center (CAPSad). The music workshops were conducted daily by a trained professional, lasting one hour each. At the end of one week the index of satisfaction of the participation in the workshop was measured by the scale of Subjective Well-Being [12]. The results indicate a significant improvement on the feeling of positive affection after the termination of music therapies. These findings allow the reflection on the use of music in favor of the individual, to obtain better results in the patient's compliance and adherence during the treatment, transposing the barriers that hinder this process, generating physical, psychic and social well-being of the individual [13]. Music as a therapeutic language provides to the individual an approximation with his social reality, since music has cultural factors, capable of reconnecting the patient with his cultural values. Thus, favoring the reconstruction of his history since treatment to drug users is a long and painful process for both the user and the family [13].

\section{Conclusion and Perspectives}

The use of music therapy in individuals who abuse alcohol and drugs contributes to an increase in the physiological perception of well-being, and this may directly implicate the way in which they adhere to treatment. The experiences of the researchers, plus the results obtained in this intervention, evidences the need for future investigations, to improve the strategies adopted by professionals working in this area.

\section{References}

1. Bergold, Leila Brit, Alvim, Neide Aparecida Titonelli, et al. (2006) 0 lugar da música no espaço do cuidado terapêutico: sensibilizando enfermeiros com a dinâmica músical. Texto Contexto Enferm 15(2): 262-269.

2. Kimberly SM (2018) Neurologic Foundations of Music-Based Interventions. Music Therapy: Research and Evidence-Based Practice, Elsevier, Amsterdam, Netherlands, p. 15-27.

3. Lori F, Gooding (2018) Music Therapy in Mental Health Treatment. Music Therapy: Research and Evidence-Based Practice Elsevier, Amsterdam, Netherlands, p. 47-61.

4. Brasil (2004) A política do Ministério da Saúde para atenção integral a usuários de álcool e outras drogas. Ministério da Saúde.

5. Kubota AMA, Magalhães ACR, Santos V, Gallassi AD (2013) Terapia ocupacional na abordagem de pessoas em tratamento por anorexia nervosa. Saúde (Santa Maria) 39(2): 2334.

6. Souza AL, Rodrigues MOC, Carnaúba FP, Barbosa LR (2013) A utilização da terapia do humor no ambiente hospitalar: revisão integrativa. Saúde (Santa Maria) 39(2): 4956.

7. Andrade RLP, Pedrão LJ (2005) Algumas considerações sobre a utilização de modalidades terapêuticas não tradicionais pelo enfermeiro na assistência de enfermagem psiquiátrica. Rev Latino-am Enfermagem 13(5): 737-742.

8. Hatem TP, Lira PIC, Mattos SS (2006) Efeito terapêutico da música em crianças em pós-operatório de cirurgia cardíaca. J Pediatr 82(3): 186192.

9. Gerassimowitsch G, Sidorenko W, Kuptschina A, Teterkina T, Korotkow S (2006) Reduction of Hypertonia. Madrid, Spain.

10. Benkovitz D (2008) Music therapy and pain management. 12 Congreso Mundial de Musicoterapia Anais. Librería Akadia Editorial Buenos Aires, Argentina, p. 49-50.

11. HanserS(2008)Canmusicmakeushealthy?Thepsychoneuroimmunology of music. 12 Congreso Mundial de Musicoterapia Anais, Librería Akadia Editorial, Buenos Aires: Argentina, pp. 318-319.

12. Diener E, Suh EM, Lucas RE, Smith HL (1999) Subjective Well-Being: Three Decades of Progress. Psychological Bulletin 125(2): 276-302.

13. Fontanella BJB, Turato ER (2002) Barreiras na relação clínico-paciente em dependentes de substâncias psicoativas procurando tratamento. Rev. Saúde Pública 36(4): 439-447.

\section{Your next submission with Juniper Publishers will reach you the below assets}

- Quality Editorial service

- Swift Peer Review

- Reprints availability

- E-prints Service

- Manuscript Podcast for convenient understanding

- Global attainment for your research

- Manuscript accessibility in different formats

( Pdf, E-pub, Full Text, Audio)

- Unceasing customer service

Track the below URL for one-step submission https://juniperpublishers.com/online-submission.php 